\title{
The Adoption of Digital Games Among Older Adults
}

\author{
Nurul Farinah Mohsin ${ }^{1}$, Suriati Khartini Jali ${ }^{2}$, Sylvester Arnab $^{3}$, Mohamad Imran Bandan ${ }^{4}$, Minhua Ma ${ }^{5}$ \\ Faculty of Computer Science and Information, Universiti Malaysia Sarawak, Kota Samarahan, Malaysia ${ }^{1,2,4}$ \\ Disruptive Media Learning, Coventry University, United Kingdom ${ }^{3}$ \\ Falmouth University, Cornwall, United Kingdom ${ }^{5}$
}

\begin{abstract}
The revolution of technology brings many benefits towards diverse population. Digital game is one of the digital technologies that has potential to facilitate older adults' daily routine. However, some of them faces challenges to adopt the usage of digital games in their daily lives, one of which is that most commercial games are not suitable for older people. This paper discusses the investigation into the challenges associated with the older adults' adoption of digital games, their interaction, and experiences with digital games and specifically explores the andragogical perspectives, and game design attributes. A set of questionnaires consisted of open-ended and close-ended questions were distributed, targeting the older adults across Malaysia, using online and non-probability sampling technique. 81 respondents were recruited, and 56 respondents $(n=56)$ were eligible in this study. Four participants were recruited for informal interview session. The analysis of the results indicates that the older adults' perception of digital games and game design aspects are the major factors influencing their digital game adoption. Game designs are important to attract many older adults to experience and interact with digital games.
\end{abstract}

Keywords_Digital games; Malaysia; older adults; technology

\section{INTRODUCTION}

The number of older adults in Malaysia has increased from 3.4 million in 2019 to 3.5 million in 2020, and by 2030, more than $15 \%$ of the Malaysian population will be the older population [1]. [2] stated that in Malaysia older adults aged 60 and over are categorised based on the United Nations (UN) age capping. Two main factors that contribute to the increasing number of the older population in Malaysia are lower birth rates and the declining Total Fertility Rate (TFR) [3]. Older adults tend to experience negative ageing effects such as declining in cognitive abilities and physical abilities. The advancement of digital technology such as digital games can help to facilitate the negative ageing. Digital game technology has benefits beyond the purpose of enjoyment, where it has increasingly been applied as a tool for psychological, cognitive, and neuropsychological rehabilitation for older adults [4]. Despite the benefits of digital game technology for the older population, certain older adults may confront difficulties and challenges when it comes to experiencing and participating in it.

The main problem is the game design is not suitable for older adults and does not consider their incapacity. Most of the commercialized digital games are design and develop for the general type of game and aiming for the younger user in mind.

Games specifically designed for older adults are not commercially available yet [5]. Some of the exergames can be used as a tool for exercising however, older adults who experience a decline in physical abilities might not be able to obtain a complete gaming experience due to limited physical movements. Some digital games were designed with a complex interface. Older adults who experience cognitive issues might have difficulties interacting with these games.

This paper discusses the challenges faces by the older adults aged 55 to 75 within the Malaysian context, their gaming experiences and interactions with digital games, and the associated influencing factors associated with the andragogical perspectives, and game design attributes. There are two research questions aimed to be addressed in this study:

Research question 1: What are the challenges related to older adults' interaction with digital game technology that needs to be considered?

Research question 2: How can their gaming experiences inform design considerations?

\section{LITERATURE REVIEW}

Various studies have highlighted challenges associated with older adults' experience of digital games. One of the critical factors that often influence their engagement with digital technology is the psychological factor. For instance, the fear of their inability to use technologies correctly often affects their confidence and level of readiness and acceptance [6]. Blažič and Blažič [7] suggested the root of the problem is the gap in knowledge on how to use digital devices effectively. Other factors include the natural ageing characteristics such as the decline in cognitive and physical abilities, which was not considered during the design of technologies such as games.

Game designs are classified as mechanics, dynamics, and aesthetics. Game mechanics and dynamics design refer to the interaction aspect and how the game operates. Aesthetics, on the other hand, covers the interface design in the game, the look and feel as perceived by the player. Garcia et al. [8] revealed in their study that participants have difficulties remembering certain features in the game and are confused with the game interface that presents too many options. It is essential for digital games designed for older players to have a user-friendly interface, on easy-to-use platform, and are simple to learn [9]. The number of researchers that design and develop games for older adults is still relatively limited. As stipulated by [10], most games do not consider older adults' needs and interests. There is also a lack of research that correlates the attributes of game technology with andragogical considerations and challenges faced by the target group.

To overcome the challenges, it is crucial to embed andragogical perspectives while designing and developing the 
digital game for older adults to help them throughout the learning process. Andragogy is the art and science helping adult learners. There are six fundamental principles in andragogy [11], (1) learner's need to know, (2) self-concept of the learner, (3) prior experience of the learner, (4) readiness to learn, (5) orientation of learning and (6) motivation to learn. According to [12], the process of learning something new for older adults would be more accessible when they know the benefits and relevance of the technology in their daily life. They have conducted a study with older adults aged 55 and above in Coventry, United Kingdom. Based on their findings, the participants learned new knowledge when they engaged with the digital games, they thought were beneficial. In this study, the adoption of digital game among older adults in Malaysia were considered to construct a framework for designing and developing game for older adults using andragogical perspectives.

The purchasing power of the elderly consumers is growing and is expected to rise rapidly in the next decade due to the ageing population globally. Leisure and entertainment, such as digital game, form a considerable share of an average senior's budget. The findings of this study will inform and help game designers developing products for this fast-growing market.

\section{MATERIALS AND METHODS}

This section discusses the materials and methodology used to conduct this study. The recruitment process of participants for this study will be discussed in Section A, instruments used will be explained in Section B and data collection and analysis procedures will be described in Section C. Fig. 1 depicts the flow of this study.

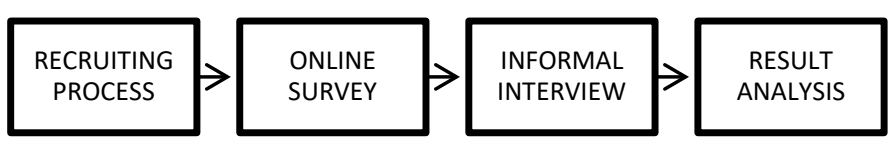

Fig. 1. Study Flow.

\section{A. Participants}

This study targeted Malaysians between 55 and 75 years old who resided in Malaysia during the study period, regardless of their experience in digital games. The recruitment of participants used convenience and snowball sampling techniques. An online survey link was distributed and disseminated using social media platforms (e.g., Whatsapp, Facebook, Telegram, Instagram, Twitter, Microsoft Outlook). All eligible participants provided informed consent online before completing the survey administered via Google Form.

\section{B. Instruments}

The study implemented a set of questionnaires that consisted of open- and close-ended questions categorised under six key sections: (1) participant background, (2) technology usage, (3) game experience, (4) game usability, (5) challenges, and game recommendation, and (6) opinion and suggestion. The questionnaire was disseminated to the target participants via an online survey (Google Form). All participants were required to complete Sections 1 and 2. Subsequently, participants who indicated experience in digital games were given access to Section 3-5 in the questionnaire.

Section 1 Participant background was used to gather the demographic background of the respondents. Section 2 contains questions on technology use, which were used to ascertain participants' computer abilities and familiarity with digital games. Those who have experience with digital games then answered Sections 3 and 4, which are used to assess the game experience and the usability of the game played by the respondents. The game experience was measured by using Game Experience Questionnaire (GEQ) [13], and the game usability was measured by using the System Usability Scale (SUS) [14]. The GEQ was adopted from [15].

Section 5 asked the participants to discuss their challenges and recommendations on game design based on their prior gaming experience. Finally, in Section 6, participants could give their opinions on the usage of the digital game among older adults in Malaysia.

\section{Data Collection and Analysis Procedure}

All data collected via Google Form was stored in Microsoft Excel. The responses from the participants were analysed quantitatively. The Statistical Package for the Social Sciences (SPSS) software (version 22; SPSS Inc., Chicago, IL, USA) was used to assist the researchers in analysing the data. Two types of statistical analysis were used in this study. Descriptive analysis was used to analyse the participants' background, and Chi-Square was used to test the association between participants' computer skills and their experience playing digital games. Responses from the open-ended questionnaire were discussed qualitatively. Informal interview sessions with four participants were conducted. The sessions were recorded using audio recorder and data were analysed.

\section{RESULTS}

In this section, results obtained from the questionnaire were discussed. Section A addresses the participants' backgrounds. Section B discusses the participants' technology use. Section C explains the participants' computer abilities and experience with digital games. Finally, section 4.4 highlights the obstacles that may affect older people's digital game use.

In this study, 81 responses were recorded, however, due to the targeted age group of 55 to 75 years old for this study, we excluded 25 responses as they are not in the age range. Based on the data obtained, 41 of the participants were between the age of 55-60 years old, followed by an age range between 6165 years old $(n=9), 66-70$ years old $(n=5)$, and $71-75$ years old $(n=1) .33$ of the participants were female and 23 were males. Based on the participants' marital status, 45 of them were married, 9 were widowed, 1 was single, and 1 was divorced. In terms of employment status, 20 of the participants were fulltime workers, 20 retired, 13 were unemployed, and 3 were in part-time employment. All respondents were recruited from Malaysia, where 24 of them are from Sabah, followed by Sarawak $(n=14)$, Wilayah Persekutuan $(n=4)$, Selangor $(n=4)$, Pahang $(n=3)$, Melaka $(n=2)$, Perak $(n=1)$, Johor $(n=1)$, and Perlis $(n=1)$. 
Informal interview session was involved with four participants from different districts and state in Malaysia. 2 female participants are from Kota Kinabalu Sabah, while remaining 2 male participants are from Labuan and Perak respectively.

\section{A. Technologies usage among Participants}

This section of the questionnaire required respondents to give information on their technology usage. Participants were required to state their computer skills, type of devices owned, and their experience using digital games. Based on the result obtained, 4 participants rated their computer skills as 'expert', 17 rated 'competent', 24 rated 'novice', and 11 of them rated themselves as none. In response to the question: "What kind of devices you own", most of the participants owned at least one type of digital device. 41 of the participants owned a smartphone.

The focus of this study is to investigate their game experience and game consideration. Based on the responses obtained, only 10 of the respondents had experience in using digital games. Table I presents the game name and game type played by the respondents. Most participants who indicated 'No' for their experience in using digital game stated that playing digital games is a waste of time. They mentioned how they are not interested in playing and thought that playing digital games is irrelevant for older populations.

\section{B. Relationship between Computer Skills, Employment Status, and Experience with Digital Games}

Table II shows the crosstabulation between participants' computer skills, employment status, and their experience in playing digital games. Based on the result obtained, those with experience playing digital games were novice and competent participants from various employment statuses. The skills and employment status were not influenced the participants' experience in playing digital games.

TABLE I. Game Name and Game Type Played by the Respondents

\begin{tabular}{|l|l|l|l|}
\hline Game Name & Game Type & $\begin{array}{l}\text { Frequency } \\
\text { (n) }\end{array}$ & $\begin{array}{l}\text { Percentag } \\
\text { e (\%) }\end{array}$ \\
\hline Candy crush & Puzzle & 7 & 70 \\
\hline Word Search & Puzzle & 3 & 30 \\
\hline Bubble & Puzzle & 2 & 20 \\
\hline Toybear & Puzzle & 1 & 10 \\
\hline Bubblesoap & Action & 1 & 10 \\
\hline Deer Hunter & Simulation & 1 & 10 \\
\hline Galaxy Force & $\begin{array}{l}\text { Third Person } \\
\text { Shooter Game }\end{array}$ & 1 & 10 \\
\hline $\begin{array}{l}\text { Player Unknown } \\
\text { (PUBtle Ground }\end{array}$ & $\begin{array}{l}\text { First Person Shooter } \\
\text { Game }\end{array}$ & 1 & 10 \\
\hline Mobile Legend (ML) & Adventure & 1 & 10 \\
\hline Farm Ville & Simulation & 1 & 10 \\
\hline Angry Bird & Puzzle & 1 & 10 \\
\hline Mario & Adventure & 1 & 10 \\
\hline Word Puzzle & Puzzle & 1 & 10 \\
\hline
\end{tabular}

TABLE II. CROSS TABULATED RESULTS OF SKILLS, EMPLOYMENTS STATUS, AND RESPONDENTS' EXPERIENCE PLAYING WITH DIGITAL GAMES

\begin{tabular}{|c|c|c|c|c|c|}
\hline \multicolumn{3}{|l|}{ Skills } & \multicolumn{2}{|c|}{$\begin{array}{l}\text { Experience } \\
\text { Digital Game }\end{array}$} & \multirow{3}{*}{\begin{tabular}{|l} 
Total \\
2
\end{tabular}} \\
\hline & & & \multirow{2}{*}{$\begin{array}{l}\text { Yes } \\
0\end{array}$} & \multirow{2}{*}{$\begin{array}{l}\text { No } \\
2 \\
\end{array}$} & \\
\hline \multirow{3}{*}{ Expert } & \multirow{2}{*}{$\begin{array}{l}\text { Employment } \\
\text { Status }\end{array}$} & Full time & & & \\
\hline & & Retired & 0 & 2 & 2 \\
\hline & \multicolumn{2}{|l|}{ Total } & 0 & 4 & 4 \\
\hline \multirow{4}{*}{ Competent } & \multirow{3}{*}{$\begin{array}{l}\text { Employment } \\
\text { Status }\end{array}$} & Full time & 2 & 7 & 9 \\
\hline & & Part time & 0 & 2 & 2 \\
\hline & & Retired & 2 & 4 & 6 \\
\hline & \multicolumn{2}{|l|}{ Total } & 4 & 13 & 17 \\
\hline \multirow{5}{*}{ Novice } & \multirow{4}{*}{$\begin{array}{l}\text { Employment } \\
\text { Status }\end{array}$} & Full time & 2 & 6 & 8 \\
\hline & & Part time & 0 & 1 & 1 \\
\hline & & Retired & 1 & 8 & 9 \\
\hline & & Unemployed & 3 & 3 & 6 \\
\hline & \multicolumn{2}{|l|}{ Total } & 6 & 18 & 24 \\
\hline \multirow{4}{*}{ None } & \multirow{3}{*}{$\begin{array}{l}\text { Employment } \\
\text { Status }\end{array}$} & Full time & 0 & 1 & 1 \\
\hline & & Retired & 0 & 3 & 3 \\
\hline & & Unemployed & 0 & 7 & 7 \\
\hline & \multicolumn{2}{|l|}{ Total } & 0 & 11 & 11 \\
\hline
\end{tabular}

A Chi-Square test was conducted to test the association between participants' computer skills and their experience playing the digital game. Table III shows the results of the ChiSquare test between computer skills and participants' experience playing digital games. Results revealed that there is no association between computer skills and experience playing digital games, $\chi 2=4.469 \mathrm{a}, \mathrm{p}=.215$. Thus, there is no association found between computer skills and gameplay experience among the participants. Based on the findings, the level of participants' computer literacy is not a major factor that affects their engagement with digital games as those who considered themselves as competent or novice were more engaged with digital games than those who considered themselves as an expert.

TABLE III. CHI-SQUARE TESTS

\begin{tabular}{|c|c|c|c|}
\hline & Value & df & p-value \\
\hline Pearson Chi-Square & $4.469 \mathrm{a}$ & 3 & .215 \\
\hline Likelihood Ratio & 7.010 & 3 & .072 \\
\hline Linear-by-Linear Association & .372 & 1 & .542 \\
\hline $\mathrm{N}$ of Valid Cases & 56 & & \\
\hline
\end{tabular}

\section{Challenges that may Impact Older Adults' used of Digital Games}

In this section, responses from participants who indicated have experience with digital games are discussed based on the questions in Sections 3 to 6 in the questionnaire. There were two research questions related to these sections. 
Research Question 1: What are the challenges related to the older adults' interaction with digital game technology that needs to be considered?

Based on our findings, the game design played by the respondents was one of the challenges for them to interact with digital game technology. Older adults might be affected by negative ageing impacts, for example, the decline in physical and cognitive abilities. Participant 18, said, "tulisan kecil" (small wordings) is one of the challenges for her to adapt to digital game technology. Apart from that, the screen size of devices used during the gameplay session was small and it affected their gameplay session. According to the principles of andragogy, older adults must have self-concept and experience with the platform used to play the digital game so that they can fully control the gaming experience.

Besides game design, the perception of older adults is one of the challenges to attract them to play the digital game. In Section 6 of the questionnaire, participants can give their opinion regarding the usage of digital games among older adults. Based on the findings, most of the participants find digital games irrelevant for older populations and perceive playing games as a waste of time. Also, some of them are not interested in playing digital games and feel that digital game interaction is complicated and challenging. One of the respondents commented, "kurang memberi faedah" (give fewer benefits) on question asking opinions regarding the usage of digital games among older adults. Despite the generally negative views on games, one of the respondents stated that digital games can be used as a tool to relieve stress, but older adults need to get proper guidance on how to use them as some older adults are not familiar with digital games.

Research Question 2: How can their game experiences inform design consideration?

A reliability test was conducted to identify the internal consistency and specified measurement's usability. Cronbach's Alpha defines the internal consistency or average correlation of items in the GEQ. The Cronbach's Alpha value is 0.820 where it is acceptable and reliable [16]. GEQ is a well-established questionnaire used in many previous studies [17, 18, 19, 20]. Santos et al. [17] used GEQ to report their participants' experience during game play and their sense of social presence.

As mentioned earlier, only 10 out of 56 participants had experience in engaging with digital games. Game Experience Questionnaire (GEQ) was used to measure their level of experience during gameplay sessions [15]. We used the 5Likert scale (strongly disagree, disagree, neutral, agree, strongly agree). GEQ consists of 33 items, and they measure 7 players' experiences include immersion, flow, competence, tension, challenge, positive affect, and negative affect during gameplay sessions.

Table IV presents the results for positive affect items in the GEQ. Positive items measure players' emotional experience (e.g., enjoyment). The results show that most of the participants agreed that the gaming experience brings a positive effect on them. Cronbach's Alpha value for positive items is 0.957 . The questions "I thought it was fun" and "I felt happy” have the highest mean values $(M=3.90)$. This indicates that the respondents' gaming experience was fun, and they felt happy during gameplay. The mean for the question "I felt content" has the lowest mean value $(M=3.20)$ and it might be influenced by the theme of the games played by the participants. This question linked to the andragogy principle, where the participants were not content during the gameplay session. Based on our findings, we found that the participants who respond neutrally in this question played puzzle game type. Each participant played a different type of digital game, where their emotional feeling towards the gaming experience might be different from others.

The second item measured in GEQ is competence and the Cronbach's Alpha value is 0.833. Based on the findings, most of the participants' scores were neutral except for the question "I felt successful" where they agreed based on their gaming experience. However, one of the participants strongly disagreed with the question "I felt successful". This result might be influenced by the game type played by participant which was Word Puzzle. The game requires greater effort to solve a puzzle than other puzzle games and if the player could not solve it, they might feel unsuccessful and frustrated. Table $\mathrm{V}$ illustrates the results for competence items. One of the participants during the interview session suggested to include the scoreboard elements in the game. He said the element can gives satisfaction during gameplay session as he can see the progress score when he plays the game.

TABLE IV. SUMMARY OF POSITIVE ITEMS

\begin{tabular}{|l|l|l|l|l|l|l|l|}
\hline & $\mathbf{N}$ & Min & Max & Mode & Sum & Mean & $\begin{array}{l}\text { Std. } \\
\text { Deviation }\end{array}$ \\
\hline I felt content & 10 & 2 & 4 & 3 & 32 & 3.20 & .632 \\
\hline $\begin{array}{l}\text { I thought it } \\
\text { was fun }\end{array}$ & 10 & 3 & 4 & 4 & 39 & 3.90 & .316 \\
\hline I felt happy & 10 & 2 & 5 & 4 & 39 & 3.90 & .876 \\
\hline I felt good & 10 & 2 & 4 & 4 & 37 & 3.70 & .675 \\
\hline I enjoyed it & 10 & 2 & 5 & 4 & 37 & 3.70 & .949 \\
\hline $\begin{array}{l}\text { Valid N } \\
\text { (listwise) }\end{array}$ & 10 & & & & & & \\
\hline
\end{tabular}

TABLE V. SUMMARY OF COMPETENCE ITEMS

\begin{tabular}{|l|l|l|l|l|l|l|l|}
\hline & N & Min & Max & Mode & Sum & Mean & $\begin{array}{l}\text { Std. } \\
\text { Deviation }\end{array}$ \\
\hline $\begin{array}{l}\text { I felt } \\
\text { skillful }\end{array}$ & 10 & 2 & 4 & 3 & 31 & 3.10 & .568 \\
\hline $\begin{array}{c}\text { I felt } \\
\text { competent }\end{array}$ & 10 & 3 & 4 & 3 & 34 & 3.40 & .516 \\
\hline $\begin{array}{c}\text { I was good } \\
\text { at it }\end{array}$ & 10 & 3 & 5 & 3 & 35 & 3.50 & .707 \\
\hline $\begin{array}{l}\text { I felt } \\
\text { successful }\end{array}$ & 10 & 1 & 5 & 4 & 36 & 3.60 & 1.075 \\
\hline $\begin{array}{l}\text { I was fast at } \\
\text { reaching the } \\
\text { game's } \\
\text { targets }\end{array}$ & 10 & $\mathrm{z}$ & 4 & 3 & 31 & 3.10 & .738 \\
\hline $\begin{array}{l}\text { Valid N } \\
\text { (listwise) }\end{array}$ & 10 & & & & & & \\
\hline
\end{tabular}


TABLE VI. SUMMARY OF IMMERSION ITEMS

\begin{tabular}{|l|l|l|l|l|l|l|l|}
\hline & N & Min & Max & Mode & Sum & Mean & $\begin{array}{l}\text { Std. } \\
\text { Deviation }\end{array}$ \\
\hline $\begin{array}{l}\text { I was } \\
\text { interested in } \\
\text { the game's } \\
\text { storyline }\end{array}$ & 10 & 2 & 5 & 4 & 34 & 3.40 & 1.075 \\
\hline $\begin{array}{l}\text { It was } \\
\text { aesthetically } \\
\text { pleasing }\end{array}$ & 10 & 1 & 5 & 3 & 32 & 3.20 & 1.033 \\
\hline $\begin{array}{l}\text { I felt } \\
\text { imaginative }\end{array}$ & 10 & 2 & 4 & 3 & 29 & 2.90 & .738 \\
\hline $\begin{array}{l}\text { I felt that I } \\
\text { could } \\
\text { explore } \\
\text { things }\end{array}$ & 10 & 1 & 5 & 4 & 33 & 3.30 & 1.160 \\
\hline $\begin{array}{l}\text { I found it } \\
\text { impressive }\end{array}$ & 10 & 1 & 5 & 4 & 34 & 3.40 & 1.174 \\
\hline $\begin{array}{l}\text { It felt like a } \\
\text { rich } \\
\text { experience }\end{array}$ & 10 & 2 & 4 & 3 & 32 & 3.20 & .632 \\
\hline $\begin{array}{l}\text { Valid N } \\
\text { (listwise) }\end{array}$ & 10 & & & & & & \\
\hline
\end{tabular}

Table VI shows the results obtained for the immersion aspect. There were six questions in the immersion item and the Cronbach's Alpha value is 0.904 . Based on the findings, most of the participants were either neutral or agreeable on the immersion questions on their previous gaming experience.

There are five questions related to flow items. Table VII depicts the results from preliminary analysis for flow items. The Cronbach's Alpha value for flow items is 0.823. A majority of the participants agreed on the "I forgot everything around me" and "I was deeply concentrated in the game" items. This indicates the participants were focused during the gameplay session.

The results obtained from the preliminary analysis of negative affect during the gameplay experience are shown in Table VIII Cronbach's Alpha value for negative items is 0.821 . Most of the participants disagreed with the negative effect during gameplay, such as giving them a bad mood or feeling bored. For the aspects related to "I thought about other things" and "I found it tiresome", most of the participants responded neutrally; perhaps influenced by the type of game that they played.

One of the participants in the interview session said he feels frustrated during the gameplay session when he cannot reach or complete the task in game after few times attempt. Furthermore, he said this kind of frustration can lead to decrease the level of desire to proceed with gameplay session.

There are five items measured in challenges as listed in Table IX. The Cronbach's Alpha value is 0.844 . Based on the results obtained, most of the respondents disagreed with the question "I felt pressured" and "I felt time-pressured". These questions reflected the games played by the respondents, where most of the games played by them do not have a time limit to complete the task.

During the interview session, participants were asked regarding their opinion on digital games and the features they want in the game. Some of the like challenges, elements in the game, there it gives satisfaction to them during gameplay session. However, one of the participants said she preferred an easy game where it does not require much effort to play and control the game and with no complicated instruction to learn and understand.

TABLE VII. SUMMARY OF FLOW ITEMS

\begin{tabular}{|l|l|l|l|l|l|l|l|}
\hline & $\mathbf{N}$ & Min & Max & Mode & Sum & Mean & $\begin{array}{l}\text { Std. } \\
\text { Deviation }\end{array}$ \\
\hline $\begin{array}{l}\text { I was fully } \\
\text { occupied } \\
\text { with the } \\
\text { game }\end{array}$ & 10 & 2 & 5 & 3 & 32 & 3.20 & .919 \\
\hline $\begin{array}{l}\text { I forgot } \\
\text { everything } \\
\text { around me }\end{array}$ & 10 & 2 & 4 & 4 & 32 & 3.20 & .919 \\
\hline $\begin{array}{l}\text { I lost track of } \\
\text { time }\end{array}$ & 10 & 2 & 5 & 2 & 31 & 3.10 & 1.101 \\
\hline $\begin{array}{l}\text { I was deeply } \\
\text { concentrated } \\
\text { in the game }\end{array}$ & 10 & 1 & 5 & 4 & 37 & 3.70 & 1.160 \\
\hline $\begin{array}{l}\text { I lost } \\
\text { connection } \\
\text { with the } \\
\text { outside } \\
\text { world }\end{array}$ & 10 & 1 & 5 & 2 & 26 & 2.60 & 1.174 \\
\hline $\begin{array}{l}\text { Valid N } \\
\text { (listwise) }\end{array}$ & 10 & & & & & & \\
\hline
\end{tabular}

TABLE VIII. SUMMARY OF NEGATIVE ITEMS

\begin{tabular}{|l|l|l|l|l|l|l|l|}
\hline & $\mathbf{N}$ & Min & Max & Mode & Sum & Mean & $\begin{array}{l}\text { Std. } \\
\text { Deviation }\end{array}$ \\
\hline $\begin{array}{l}\text { It gave } \\
\text { me a bad } \\
\text { mood }\end{array}$ & 10 & 1 & 5 & 2 & 23 & 2.30 & 1.160 \\
\hline $\begin{array}{c}\text { I thought } \\
\text { about } \\
\text { other } \\
\text { things }\end{array}$ & 10 & 1 & 4 & 3 & 30 & 3.00 & .816 \\
\hline $\begin{array}{l}\text { I found it } \\
\text { tiresome }\end{array}$ & 10 & 1 & 4 & 3 & 29 & 2.90 & .876 \\
\hline $\begin{array}{c}\text { I felt } \\
\text { bored }\end{array}$ & 10 & 2 & 3 & 2 & 24 & 2.40 & .516 \\
\hline $\begin{array}{l}\text { Valid N } \\
\text { (listwise) }\end{array}$ & 10 & & & & & & \\
\hline
\end{tabular}

TABLE IX. SUMMARY OF CHALLENGE ITEMS

\begin{tabular}{|l|l|l|l|l|l|l|l|}
\hline & N & Min & Max & Mode & Sum & Mean & $\begin{array}{l}\text { Std. } \\
\text { Deviation }\end{array}$ \\
\hline $\begin{array}{l}\text { I thought } \\
\text { it was hard }\end{array}$ & 10 & 1 & 5 & 3 & 30 & 3.00 & 1.155 \\
\hline $\begin{array}{l}\text { I felt } \\
\text { pressured }\end{array}$ & 10 & 2 & 5 & 2 & 29 & 2.90 & 1.287 \\
\hline $\begin{array}{l}\text { I felt } \\
\text { challenged }\end{array}$ & 10 & 2 & 5 & 3 & 34 & 3.40 & 1.075 \\
\hline $\begin{array}{l}\text { I felt time } \\
\text { pressure }\end{array}$ & 10 & 2 & 4 & 2 & 27 & 2.70 & .823 \\
\hline $\begin{array}{l}\text { I had to put } \\
\text { a lot of } \\
\text { effort into } \\
\text { it }\end{array}$ & 10 & 2 & 5 & 3 & 32 & 3.20 & .919 \\
\hline $\begin{array}{l}\text { Valid N } \\
\text { (listwise) }\end{array}$ & 10 & & & & & & \\
\hline
\end{tabular}


TABLE X. SUMMARY OF TENSION ITEMS

\begin{tabular}{|l|l|l|l|l|l|l|l|}
\hline & N & Min & Max & Mode & Sum & Mean & $\begin{array}{l}\text { Std. } \\
\text { Deviation }\end{array}$ \\
\hline $\begin{array}{l}\text { I felt } \\
\text { annoyed }\end{array}$ & 10 & 1 & 4 & 2 & 24 & 2.40 & .843 \\
\hline $\begin{array}{c}\text { I felt } \\
\text { irritable }\end{array}$ & 10 & 1 & 4 & 2 & 25 & 2.50 & .972 \\
\hline $\begin{array}{c}\text { I felt } \\
\text { frustrated }\end{array}$ & 10 & 1 & 4 & 2 & 26 & 2.60 & 1.075 \\
\hline $\begin{array}{l}\text { Valid N } \\
\text { (listwise) }\end{array}$ & 10 & & & & & & \\
\hline
\end{tabular}

It can be seen from findings shown in Table $\mathrm{X}$ that most of the participants disagreed on the tension items. Digital games are often known as a tool that can bring enjoyment to the players. One of the participants in this study agreed that the gaming experience made him annoyed, irritable, and frustrated. Based on the game name indicated by the participant, we found that he played Deer Hunter and Galaxy Force game. Both games played by the participant required him to achieve the target in the game. Thus, it might influence his feeling during the gameplay session. The Cronbach's Alpha value is 0.957.

The game evaluation used in this study is SUS, and the Cronbach's Alpha value is 0.539 . The value is unacceptable as it is below 0.60. The reliability of SUS in this study is inconsistent as every user experienced a different type of user interface based on their previous gameplay session. The overall score for the SUS value is 56.25 . This value is acceptable and falls in the marginal range for the SUS score [21] F-+ig. 2.

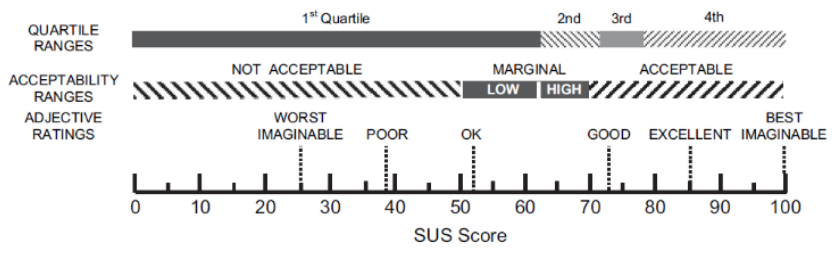

Fig. 2. SUS Adjective Rating [21].

\section{DISCUSSION}

From the survey results, only $18 \%$ of the total participants have experience in playing digital games. We found that the main factor that influences older adults to interact and experience digital games is their perception of digital games. It is important to ensure older adults acknowledge the benefits they gained from playing digital games. Apart from using it as an entertainment tool, digital games can be used as an innovative healthcare platform.

Computer skills do not affect the participants' experience with the digital game. Older adults who indicated their skills as competent and novice have had experience with digital games compared to those who indicated their skills as an expert. The game design is the main factor that influences the game experiences for older adults.

Based on the list of games played by the respondents, most of them were designed with no time pressure to help older adults focus on gameplay and distract them from feeling time pressure. The most popular game genre played by the participants in this study is puzzle, where it was designed with simple operation and highly achievable goals. Owing to older adults' decline in cognitive capacity, simple games may appeal to older adults. Apart from that, playing puzzle games does not require complex computing skills, making it more straightforward for older adults to play. Furthermore, puzzle game is a type of game that is familiar to this population, and it does not require them to learn new things, and the in-game instruction and rules are not complicated.

In our findings, most of the games played were puzzle games with a limited storyline for the player to immerse in the gaming experience and imagination may be limited during gameplay sessions. The participants played the CandyCrush game, where it is a part of a puzzle game. The game's mechanics and dynamics are repetitive, where it does not change and give the element of surprise to the players. As a result, they might feel tired and not enjoying the gameplay. It is important to design game with surprise elements to ensure the player enjoy throughout the gaming session.

The results for immersion category were influenced by the game's storyline, interface, and the mechanics of the game played by the respondents. It is important for the aesthetics, dynamics, and mechanics in the game should be designed to cope with older adults' cognitive and physical abilities. As indicated in the principle of andragogy, older adults will feel motivated to learn something if it can attract their attention and bring benefits to them.

Older adults will give their attention to the gameplay session if they understand the game flow, aligning with the key principle of andragogy, which are the learners' self-concept and their readiness to learn new things. The results revealed that the game played by the participants can attract their attention and make them concentrate during gameplay sessions.

\section{CONCLUSION}

The findings in this paper are subject to at least three limitations. First, the number of participants eligible included in our study is relatively small. There are 81 responses recorded; however, only 56 responses are eligible to include in this study due to the age limitation. Other than the number of respondents, only ten participants have experience playing the digital games and the games they played were different. Thus, the gaming experience of the respondents might differ from other respondents. The verbal and non-verbal behavior of the participants during the gameplay session is not observed and the interview session with target people is not conducted due to the limitation to meet the respondents face-to-face during Movement Control Order (MCO) imposed in Malaysia. To overcome the limitations, it is recommended to conduct a faceto-face session with older adults to observe their verbal and non-verbal behaviour during gameplay sessions and use the same game type to measure their gaming experience. This paper has shown the data on the adoption of older adults to interact with digital technology and their opinions on the relevance of digital games towards the older population in Malaysia.

\section{ACKNOWLEDGMENT}

This research is fully supported by the Kementerian Pengajian Tinggi Malaysia, Fundamental Research Grant Scheme, FRGS/1/2019/ICT01/UNIMAS/03/1. The authors 
fully acknowledged the Ministry of Higher Education (MOHE) and Universiti Malaysia Sarawak for the approved fund, which makes this important research viable and effective.

\section{REFERENCES}

[1] Department of Statistics, Current Population Estimates, no. December. Putrajaya, Malaysia: Department of Statistics, Malaysia, 2020.

[2] N. M. Yunus, N. H. Abd Manaf, A. Omar, N. Juhdi, M. A. Omar, and M. Salleh, "Determinants of healthcare utilisation among the elderly in Malaysia," Institutions Econ., vol. 9, no. 3, pp. 117-142, 2017.

[3] W. M. S. W. Ibrahim et al., "Population and Demographics: Ageing," vol. 1, pp. 1-2, 2017.

[4] F. Zhang and D. Kaufman, "Physical and Cognitive Impacts of Digital Games on Older Adults: A Meta-Analytic Review,” J. Appl. Gerontol., vol. 35, no. 11, pp. 1189-1210, 2016.

[5] N. Khalili-Mahani et al., "For Whom the Games Toll: A Qualitative and Intergenerational Evaluation of What is Serious in Games for Older Adults,” Comput. Games J., vol. 9, no. 2, pp. 221-244, Jun. 2020.

[6] T. Yeh, F. Pai, and M. Jeng, "The Factors Affecting Older Adults , Intention toward Ongoing Participation in Virtual Reality Leisure Activities,” Int. J. Environ. Res. Public Heal. Artic., vol. 16, no. 3, 2019.

[7] B. J. Blažič and A. J. Blažič, "Overcoming the digital divide with a modern approach to learning digital skills for the elderly adults,” Educ. Inf. Technol., vol. 25, no. 1, pp. 259-279, 2019.

[8] J. A. Garcia, W. L. Raffe, and K. F. Navarro, "Assessing user engagement with a fall prevention game as an unsupervised exercise program for older people,” ACM Int. Conf. Proceeding Ser., 2018.

[9] C. T. Lin and S. S. Chuang, "A Study of Digital Learning for Older Adults,” J. Adult Dev., vol. 26, no. 2, pp. 149-160, 2019.

[10] X. Wang, X. Yao, and J. Gu, "Attraction and Addiction Factors of Online Games on Older Adults: A Qualitative Study,” Lect. Notes Comput. Sci. (including Subser. Lect. Notes Artif. Intell. Lect. Notes Bioinformatics), vol. 11593 LNCS, pp. 256-266, 2019.

[11] C. Malliarakis, F. Tomos, O. Shabalina, and P. Mozelius, "Andragogy and e.M.o.t.i.o.n.: 7 key factors of successful serious games," in
Proceedings of the 12th European Conference on Games Based Learning (ECGBL 2018) :, 2018, vol. 12, pp. 371-378.

[12] S. K. Jali and S. Arnab, "The Perspectives of Older People on Digital Gaming: Interactions with Console The Perspectives of Older People on Digital Gaming: Interactions with Console and Tablet-based Games," Vaz Carvalho C., Escudeiro P., Coelho A. Serious Games, Interact. Simulation. SGAMES 2016. Lect. Notes Inst. Comput. Sci. Soc. Informatics Telecommun. Eng., vol. 176, no. December, 2017.

[13] W. Ijsselsteijn et al., "Measuring the Experience of Digital Game Enjoyment,” J. Pers., vol. 2008, no. June 2014, pp. 7-8, 2008.

[14] R. A. Grier, A. Bangor, P. Kortum, and S. C. Peres, "The system usability scale: Beyond standard usability testing,” Proc. Hum. Factors Ergon. Soc., pp. 187-191, 2013.

[15] W. A. IJsselsteijn, Y. A. W. de Kort, and K. Poels, "The Game Experience Questionnaire," Eindhoven: Technische Universiteit Eindhoven, 2013.

[16] N. Niksadat, S. Rakhshanderou, R. Negarandeh, A. Ramezankhani, A. Vasheghani Farahani, and M. Ghaffari, "Development and Psychometric Evaluation of Andragogy-based Patient Education Questionnaire (APEQ),” Am. J. Heal. Educ., vol. 50, no. 6, pp. 390-397, 2019.

[17] L. H. Santos et al., "Pervasive game design to evaluate social interaction effects on levels of physical activity among older adults,” J. Rehabil. Assist. Technol. Eng., vol. 6, no. June, p. 205566831984444, 2019.

[18] A. Barenbrock, M. Herrlich, and R. Malaka, "Design lessons from mainstream motion-based games for exergames for older adults," Conf. Proc. - 2014 IEEE Games, Media, Entertain. Conf. IEEE GEM 2014, app. 1-8, 2015.

[19] N. A. Merriman, E. Roudaia, M. Romagnoli, I. Orvieto, and F. N. Newell, “Acceptability of a custom-designed game, CityQuest, aimed at improving balance confidence and spatial cognition in fall-prone and healthy older adults,” Behav. Inf. Technol., vol. 37, no. 6, pp. 538-557, 2018.

[20] J. Barbara, "Measuring user experience in board games,” Int. J. Gaming Comput. Simulations, vol. 6, no. 1, pp. 64-79, 2014.

[21] A. Bangor et al., "An Empirical Evaluation of the System Usability Scale Usability Scale,” vol. 7318, 2008. 